PROBLEMS

OF EDUCATION IN THE $21^{\text {st }}$ CENTURY Vol. 79 , No. 1, 2021

118

\title{
IN-SERVICE TEACHERS' PERCEPTIONS OF THE EFFECTIVENESS OF THEIR PRE-SERVICE ART EDUCATION PROGRAM IN UGANDA
}

\author{
Julius Ssegantebuka, Patrick Sserunjogi, Ritah Edopu, \\ Timothy Tebenkana, John Bosco Kanuge \\ Makerere University, Uganda \\ E-mail: segan@cedat.mak.ac.ug, ptsseru@gmail.com,rnedopu@gmail.com, \\ ttebenkana@gmail.com, jbkanuge@googlemail.com
}

\begin{abstract}
This research aimed to determine IVATs' perceptions of the effectiveness of their pre-service visual arts program in equipping them with the professional skills needed in VA teaching. Prompted by the persistent complaints about the teachers' lack of competencies that they should have acquired during their pre-service art teacher preparation, it specifically examined the VAC focusing on content, teaching methods, resources and assessment in VA and their relationship to the content gap IVATs are observing in VA teaching at the secondary school level. A qualitative approach was used to solicit participants' views about the effectiveness of their pre-service teacher education. The research was supported by the constructivist and interpretive philosophies which offer IVATs as well as tutors with the opportunity to construct their knowledge through social interaction, communication, and inquiry learning. The research was carried out at Makerere University-School of Education, which was conveniently selected because all the IVATs who participated in this research were students in this University. The researchers used a probabilistic sampling technique which uses a simple random sampling. A lottery method was used to select the desired number of 30 out of the 42 IVATs in total. Semi-structured interviews were used to collect data from 5 focus groups of second and third year IVATs. Findings revealed that there was inadequate content coverage, less use of active teaching methods, and concentration on summative assessment. The researchers recommended that the M.o.E.S together with NTCs restructure the VAC to allow adequate content coverage, use of active teaching methods and use of formative assessment for they equip the learners with knowledge and skills required in VA teaching.
\end{abstract}

Keywords: in-service visual arts teachers, constructivism, qualitative research, visual arts education

\section{Introduction}

In Uganda, pre-service arts education programs are conducted in institutions commonly known as National Teachers' Colleges (NTCs). These teacher colleges are charged with the responsibility to prepare pre-service visual arts teachers (PVATs) for the teaching profession. It is in these NTCs that PVATs acquire attitude, knowledge, and skills that they need to carry out their duties and responsibility as effective teachers (Aguti, 2003). When PVATs finish their teacher preparation and graduate with a diploma in secondary education (DSE), they are usually deployed to teach visual arts (VA) in the secondary schools. However, secondary school art teachers or practicing art teachers who would like to upgrade from diploma to bachelor's degree apply and are admitted to a three year part-time continuing professional development program referred to as in-service teacher education. Practicing art teachers admitted to in-service teacher education program are known as in-service visual arts teachers (IVATs). Therefore, they are the ones the research recruited during their second contact session which took place in NovemberDecember 2019. 
Julius SSEGANTEBUKA, Patrick SSERUNJOGI, Ritah EDOPU, Timothy TEBENKANA, John Bosco KANUGE. In-service teachers' perceptions of the effectiveness of their pre-service art education program in Uganda

PROBLEMS

OF EDUCATION

IN THE $21^{\text {st }}$ CENTURY

Vol. 79, No. 1, 2021

\section{Research Background}

The quality pre-service teacher preparation program is desired for it develops; subjectmatter knowledge for teachers, the understanding of learners and learning, the repertoire for beginning teachers and the tools to study teaching (Feiman-Nemsar, 2001). For quality preservice teacher preparation, priority must be placed on preparing teachers who can deliver highquality pedagogy and provide all students with quality learning experiences (Gore at el., 2007).

The quality of a teacher largely depends on the quality of pre-service teacher education. The quality of pre-service teacher education is directly related to the quality of instruction, curriculum, environment, inputs, processes and products of teacher training (Hussain, 2004). According to Barnes and Verwey (2008) teachers' experiences, induction phases, beliefs, curriculum materials, subject matter knowledge and pedagogical content knowledge are all factors that impact on the quality of teaching and learning. Darling-Hammond (2009) stated that the single most important determinant of what students learn is what their teachers know. Therefore, teacher qualifications, teacher's knowledge and skills make more difference for student learning than any other single factor. In the United Kingdom, the quality of pre-service teacher education is related to the model of teacher education such as competence model or accountability model and continuing professional development. It is during the initial teacher education, that the foundation for a continuing development is assured since it is presumably at this stage that important professional knowledge, skills, attitudes and understandings are formed (McPhee et al., 2003). According to Cheng (2005) the new aims of quality pre-service teacher education in Asia-pacific, reflect the perceived need to develop teachers to be facilitators who create unlimited opportunities for students' learning and multiple and sustainable developments through "triplization in education" (p. 51), that is, as an integrative process of globalization, localization, and individualization in education. According to Cheng, triplization in education results in quality teaching and learning.

Besides, available literature indicates that the quality of pre-service teacher education is also related to the models of education. The models of education are designed targeting different groups, and therefore, differ in duration. For example, pre-service teachers' model may range from two years for a diploma to five years for a degree. Other models target graduates who have had training in content areas and later join to study education. Several reasons are fronted for the creation of different models of education, they include responding to a shortage of teachers from traditional programs, dissatisfaction with the quality of graduates of traditional programs and provision of a longer period of training (Scannell, 2002). Advocates for a longer period of study in a training institution argue that it provides students with adequate general education, appropriate depth and breadth in the teaching field(s), adequate pedagogy, and field experiences, including student teaching (Scannell, 2002).

Good teaching requires four types of knowledge and skills: these are listed as having basic academic skills, thorough content knowledge of each subject to be taught, knowledge of both generic and content-specific pedagogy, and hands-on teaching skills (Ladwig, 1991). According to the National Research Council (2001) teacher quality refers to the knowledge, skills, abilities, and dispositions of teachers that enable them to engage students in rigorous, meaningful activities that foster academic learning for all students (Lauer et al, 2005). The importance of a teacher highlights the significance of how they are trained while still in the training institutions and the curriculum they are exposed to (Berry \& Van Driel, 2013). Kagoda and Ezati (2013) argued that "how teachers are prepared in terms of the courses they are exposed to pertaining to values, beliefs, attitudes for practices significantly influence how they will, in turn, prepare citizens who will be charged with various aspects of societal development" (p. $35)$. 
Julius SSEGANTEBUKA, Patrick SSERUNJOGI, Ritah EDOPU, Timothy TEBENKANA, John Bosco KANUGE. In-service teachers' perceptions of the effectiveness of their pre-service art education program in Uganda

PROBLEMS

OF EDUCATION IN THE $21^{\text {st }}$ CENTURY Vol. 79 , No. 1,2021

120

Gurney (2007) suggested that for the teacher education to be effective it should stress the understanding of the curriculum. Therefore, teachers should be prepared to understand the curriculum components which include; the underlying concepts/skills to be taught, methods of presentation, methods of practice/performance, method of assessment and understanding teaching and learning modalities and styles of the students. However, little is known about the extent to which the pre-service teacher education program equipped the IVATs with the abovelisted teaching skill in NTCs in Uganda.

During the 1960s after the departure of the expatriate teachers, Uganda faced a shortage of teachers at the secondary school level. Yet, due to poor working conditions, the government of Uganda could not attract graduates of Makerere University in large number to the teaching profession (Kagoda, 1997). This prompted the Uganda government to introduce a two-year Grade five scheme at the Institute of Teacher Education Kyambogo (ITEK) to prepare teachers who would bridge the gap left by expatriate teachers. However, the students who were recruited for teacher preparations were those who had scored low in their UACE and could not be admitted to university courses which demanded higher scores (Kagoda, 1997; see also Vegas et al., 2012). In this case, the teacher preparation programs could not produce quality teachers if those who were admitted to colleges to train as teachers were low performers.

The challenges facing Uganda's education system include the provisional of quality curricula and preparation of quality teachers. Additionally, global demands of $21^{\text {st-century }}$ quality education certainly strain the education system and the role of the teacher. Yet it is generally believed in the NTCs in Uganda that the teacher, conceivably, is the most important resource for national development and therefore, the improvement of the quality of education is dependent on the quality of teachers (Education Sector Strategic Plan-ESSP, 2005-2015). Mpowe (2002) urged that to raise the quality of teacher education and to bring about effective learning, the teachers' central role should be recognized by equipping them with necessary skills, knowledge, and attitudes to fulfil their central role. Besides, the literature indicates that achieving quality and effective pre-service teacher education, teacher education should be anchored on theories that offer learners as well as tutors with the opportunity to construct their knowledge through social interaction, communication, inquiry learning and respect for the environment (Mezirow, 1991a). Therefore, this makes constructivism the best theory to support this research.

Constructivism theory is based on three main concepts; the first is that learning is an active process in which the learner uses sensory input and constructs meaning out of it. Since constructivist's learning involves the use of senses, teacher educators should put into consideration the different experiences learners get when they interact with the environment, and design methods that will help all learners learn what they are supposed to learn.

The second concept states that Knowledge is constructed from experience. Students bring prior knowledge into a learning situation, which in turn forms the basis for their construction of new knowledge. Jonassen et al. (2003) in agreement, stated that new experiences often provide discrepancy between what learners observe and what they understand. By reflecting on the puzzling experience, learners integrate their new experiences with their prior knowledge about the world. Thus, it is important to examine the extent to which teacher educators make use of pre-service teacher characteristics which include their background experience. If the teacher educators do not start with what the learners know, the learner's readiness to learn is affected. Hence, they need to take the experience as an important starting point.

Thirdly, Knowledge is socially constructed; - obtaining knowledge and making meaning is thus a social process rather than the work of the isolated individual mind. The reflection process on the new experiences is not individually and passively done, learning being a social activity, learners will always seek out others to help them to solve problems and perform tasks (Jonassen et al., 2003). Similarly, as Mezirow (1991a) stressed that meaning perspectives are 
Julius SSEGANTEBUKA, Patrick SSERUNJOGI, Ritah EDOPU, Timothy TEBENKANA, John Bosco KANUGE. In-service teachers' perceptions of the effectiveness of their pre-service art education program in Uganda

often acquired uncritically in the course of childhood through socialization and acculturation, most frequently during significant experiences with teachers, parents, and mentors. They mirror the way our culture and those individuals responsible for our socialization happen to have defined various situations (Taylor, 1998). Therefore, teacher educators should be aware of what happens between individuals; these are high levels of interaction which involve conversation, discussions, inquiry and dialogue. The teacher educators have to employ methods that facilitate dialogue some of which are collaborative, communicative and inquiry learning (Mezirow, 1991a). Teacher educators, therefore, must be keen to whom the learners are interacting and communicating with. At the same time, it seems important for teacher educators to examine the quality of their knowledge of content, methods, resources, and assessment to find out whether they bring quality to teacher preparation, examine their practice whether they support meaningful interaction with human and environment to effective learning of the art content.

\section{Research Context}

Makerere University-Department of Distance Education, School of Education, College of Education and External Studies, provide a three-year in-service teacher program to IVATs, leading to an award of a Bachelor of Education (B.ED) Art Education. The IVATs, who are admitted to this program, are the ones who trained and graduated as generalist art teachers with a two-year DSE from NTCs in Uganda. On admission, IVATs are expected to have acquired necessary competencies during their pre-service teacher preparation in the category of twodimensional art (2D-art), three-dimensional arts (3D-art) and the theory category (DSE, 2002). It is through this VAC that pre-service teachers are expected to acquire the competencies needed for a quality art teacher. However, IVATs from different NTCs who are admitted at Makerere University-Department of Distance Education, School of Education, possess and exhibit varying content and pedagogical skills in different art disciplines. Yet NTCs use a centrally designed VAC during pre-service teacher preparation. A similar situation manifested itself in the IVATs who participated in this research. They differ in the knowledge and practical skills they have in different art disciplines.

\section{Research Aim}

The aim of this research was to determine the IVATs' perceptions of the effectiveness of their pre-service visual arts program in equipping them with the professional skills needed in $V A$ teaching in secondary schools in Uganda. To reach this aim, the following research question was asked:

What are the IVATs' perceptions of the effectiveness of their pre-service teacher education with regard to preparing them for the teaching profession?

\section{Research Methodology}

\section{General Background}

The researchers used a qualitative approach to explore the IVATs' perceptions of the effectiveness of their pre-service teacher education on which they were trained while still in NTCs in Uganda. The qualitative approach was chosen because the research sought IVATs' perceptions, feelings, attitudes and their interpretation of the effectiveness of their pre-service teacher education in equipping them with the professional skills needed in VA teaching. This research was conducted on the IVATs who had come for their second contact session which took place in November-December 2019.

\begin{tabular}{|l} 
PROBLEMS \\
OF EDUCATION \\
IN THE 21 $1^{\text {st }}$ CENTURY \\
Vol. 79, No. 1,2021 \\
\hline 121
\end{tabular} 
Julius SSEGANTEBUKA, Patrick SSERUNJOGI, Ritah EDOPU, Timothy TEBENKANA, John Bosco KANUGE. In-service teachers' perceptions of the effectiveness of their pre-service art education program in Uganda

PROBLEMS

OF EDUCATION

IN THE $21^{\text {st }}$ CENTURY Vol. 79 , No. 1, 2021

122
Sample Selection

The research was carried out at Makerere University-Department of Distance Education, School of Education, College of Education and External Studies. Makerere University is one of the many government-aided institutions currently and officially assigned to conduct inservice teacher education in Uganda. Makerere University-Department of Distance Education was conveniently selected because all the research team members are stationed at Makerere University. The visual arts teachers, who are admitted to the in-service teacher education program, are those who hold diplomas in secondary education from NTCs in Uganda. These visual arts teachers join the in-service teacher education program to upgrade their academic qualifications.

The research population all together included 42 IVATs admitted on the in-service teacher program. In this research, IVATs were the main subjects of study and major sources of data. Therefore, the researchers believed that the IVATs who participated in this research would be in a position to; a) provide valuable information about the teaching and learning in VA during their pre-service preparation; and b) sharing their lived experiences since they are already employed in schools and have a very vast experience ranging between five to twenty years of teaching, a sign of experienced IVATs in the area of arts education. In this case, only the IVATs offering VA were sampled since they related directly to the area under study. At the same time, the researchers made sure that they select participants from all the five NTCs that are government aided in Uganda. All the IVATs were approached verbally and in the written form requesting for their consent to participate in this research. Verbal requests were intended to bring the researchers face to face with the participants before the start of conducting the interviews.

The researchers used a probabilistic sampling technique in which all members of the population have an equal opportunity of being selected (Creswell, 2012; Fraenkel \& Wallen, 2006; Odiya, 2009). The probabilistic sampling technique the researchers used was a simple random sampling (SRS) to choose individuals who would be representative of the population (Creswell, 2012). In the SRS the researchers used a lottery method whereby the present population was given numbers which were written on small pieces of papers. The pieces of papers were folded, put in a bag, carefully shuffled and then drawn (Odiya, 2009). Then IVATs were asked one by one to pick a piece of paper. All IVATs who had picked papers with odd numbers were singled out from the population. The process of selecting participants using lottery method continued until the desired number of 30 IVATs was reached out of the 42 IVATs in total.

The thirty IVATs came from six colleges that are located in the Eastern, Western, Northern, Central and Southern regions. The six colleges included Mubende, Kaliro, Muni, Unyama, Kabale, and Nkozi NTCs. The IVATs who participated in this research included 21 (70\%) male and 09 (30\%) female. The participants' age groups ranged from 24-29 to 45-50. They were prepared as secondary school art teachers between the years of 1997 and 2016. The participants' teaching experiences ranged between 04 years to 21 years. The thirty randomly sampled IVATs were second and third years who had reported for their face-to-face session during school holidays of December 2019.

\section{Instrument and Procedures}

The qualitative research interviews were used to collect data for they are characterized by many features of friendly interactions to obtain valid and reliable information (Odiya, 2009). Interviews usually provide insight into participants' perspectives in a naturalistic manner (Patton, 2002; Rubin, H. J. \& Rubin, 2005). Therefore, with interviews, the researchers had 
Julius SSEGANTEBUKA, Patrick SSERUNJOGI, Ritah EDOPU, Timothy TEBENKANA, John Bosco KANUGE. In-service teachers' perceptions of the effectiveness of their pre-service art education program in Uganda

an in-depth engagement with the IVATs. The in-depth interviews with the IVATs revealed the perceptions of the effectiveness of their pre-service teacher education in equipping them with the professional skills needed in visual arts teaching. Semi-structured interviews were used for they allowed the researchers and the participants to adjust questions and answers (Bryman, 2012; Fraenkel \& Wallen, 2006; Gray, 2009). In the same way, semi-structured interviews enabled the researchers to construct meaning about the IVATs' perceptions of the effectiveness of their pre-service teacher education in equipping them with the professional skills needed in visual arts teaching in a flexible manner. Therefore, pre-determined guiding questions that could easily be adjusted depending on the course of the interview were used.

Focus group discussion (FGD) method was used because of its ability to enable the researcher to gather valuable information in detail, from a group of people under study or being researched (Odiya, 2009). During the FGDs, the researchers focused mainly on soliciting IVATs' perspectives about art content knowledge, art teaching methods, assessment methods and resources they were exposed to during their pre-service teacher preparation in visual arts in NTCs. Similarly, FGDs are recommended where a given program is being assessed (Morgan, 1997). The researchers formed five FGD and each group was composed of six IVATs. The grouping of members for each group carefully followed the former NTCs in which they had their pre-service teacher preparation. In other words, at least each FGD had a member from each of the six NTCs. Another criterion followed when forming FGD was the teaching experiences. IVATs with fewer years of teaching were grouped with those IVATs who have taught for many years. To a lesser extent, the issue of IVATs teaching in urban or rural schools came up during the formation of the FGDs, though many of them teach in rural schools. The researchers formally sought all the participants' willingness to take part in the study by signing consent forms. With the participants' permission, the researchers tape-recorded all the interviews as a way of saving time on making field notes. On top of the recorded interviews, the researchers made some notes to capture the main points as they arose and important areas to re-visit during data analysis (Rubin, H. J. \& Rubin, 2005). The researchers requested the IVATs to suggest the suitable time and venue for their group interviews, since the interviews were conducted during the face-toface session of December 2019. This was done to enable the IVATs to participate in the research with a lot of ease and comfort.

\section{Data Analysis}

Data analysis being a continuous process it started during the process of data collection (Gray, 2009; Stake, 1995). Transcribing of in-depth interview recordings were done concurrently with data collection from individual interviews and FGDs. This allowed the researchers to consult participants for further information and clarity in some research issues. To avoid bias towards the data collected from all the selected participants, the researchers constantly consulted all the in-depth interviews. The researchers consistently referred to tape-recorded interviews to keep abreast with participants' views during data analysis. The transcribed data was important in validating the tape-recorded data to ensure accuracy in reporting the findings. In the current study, issues of reliability were handled as follows: 1) the researchers used individual and group interviews, for data triangulation, as a means of establishing synchronic reliability of the study; and 2) The interviews were pilot run to establish the time it would take IVATs to answer. To find out any possible problems that might be faced in administering the instruments, the pilot also aimed at testing the clarity of the interview items. It also aimed at identifying possible inconsistencies and ambiguity in the wording of the items. The interviews were pilot run on five IVATs who were not part of the participants. Working hand in hand as researchers, necessary changes were then made in the instruments.

\begin{tabular}{l} 
PROBLEMS \\
OF EDUCATION \\
IN THE 21 $1^{\text {st }}$ CENTURY \\
Vol. 79, No. 1,2021 \\
\hline 123
\end{tabular} 
Julius SSEGANTEBUKA, Patrick SSERUNJOGI, Ritah EDOPU, Timothy TEBENKANA, John Bosco KANUGE. In-service teachers' perceptions of the effectiveness of their pre-service art education program in Uganda

PROBLEMS

OF EDUCATION

IN THE $21^{\text {st }}$ CENTURY Vol. 79 , No. 1,2021

124

Subsequent to constant reading, making reflective notes, transcriptions from the recordings, researchers embarked on the next step of formulating manageable themes from the data, which reflected the research question and theoretical perspective underpinning the study (Miles \& Huberman, 1994). The researchers developed themes by identifying ideas that kept on emerging from the data (Gray, 2009; Miles \& Huberman, 1994). The researchers carefully examined the themes to get those that explained the IVATs' perceptions of the effectiveness of their pre-service teacher education in equipping them with the professional skills needed in VA teaching. Quotations [verbatim] from interviews were used when reporting the findings to bring out issues in the data.

\section{Research Results}

\section{Visual Arts Content}

IVATs reported with excitement that they find it easy to teach pottery, graphic design, and studio technology in the secondary schools where they are employed. They reasoned that they are easy to teach because the art materials to use are available. These art materials are paper and lead pencils. Some reported that clay for pottery and textbooks for studio technology are also available. IVATs noted that the art discipline of drawing at college was composed of three wide areas, they were supposed to study which included still-life, nature studies and human figure drawing. However, IVATs explained that the human figure as a component of drawing discipline is not among the easy to teach areas; the reason being that they have limited knowledge as far as figure drawing is concerned. Most of the IVATs identified human figure drawing as one of the study areas they never studied while at college. However, one of the IVATs was quoted saying "for us we used to study human figure...every Monday our tutor could bring us magazines and ask us to draw the picture in there..." On top of that, they mentioned painting as another discipline which was poorly taught to them, followed by weaving, history of art and art appreciation, and sculpture as art disciplines which were inadequately handled. Still, some of these study areas like weaving, figure drawing and printmaking were not stand-alone; they were combined with other art disciplines and during teaching, little attention was paid to them resulting in omission.

When IVATs were asked what they do to teach themselves these art disciplines they missed during pre-service teacher education, they mentioned that they use YouTube videos, attend workshops, consulting colleagues, copy from pamphlets and some textbooks. Findings from the interviews point to the need to equip our learners with the knowledge and skills to help them interact with different teaching resources including information communication and technologies. This can help them by teaching themselves what they were not able to learn while at NTC.

The effects of poor teacher preparation are much more felt in the field when practicing teaching. This manifested itself in the IVATs' responses when asked which art discipline(s) policymakers should include or remove from the VAC. They reported history of art and art appreciation as the discipline policymakers should remove from the VAC. Reason being that the notes for history of art and art appreciation IVATs got from their tutors while at college and the ones they copied from the available pamphlets then were very hard to understand. Some IVATs further explained that up to now they have no confidence to teach the history of art and art appreciation to their secondary school students. One IVAT noted that "the teaching of the history of art was inadequately handled". However, there are some disciplines IVATs supported to be included in the VAC but after revising their content, they included studio technology, marketing and digital literacy. 
Julius SSEGANTEBUKA, Patrick SSERUNJOGI, Ritah EDOPU, Timothy TEBENKANA, John Bosco KANUGE. In-service teachers' perceptions of the effectiveness of their pre-service art education program in Uganda

When IVATs were asked to list the content gaps they are observing in art teaching at the secondary school level, majority of them agreed that the gaps are in painting, pottery, ICT, sculpture, history of art and art appreciation, weaving, printmaking, graphic design, and drawing-human figure. For instance, IVATs lamented that;

We know what modelling is, what ceramics is, but we did not have the hands-on. We just know what we know in theory. For life drawing we know what it means but how do you handle the proportions of the figure, shading, the drapery and general step by step approach to teaching drawing (Focus group interview-1).

We have gaps in teaching imaginative composition, still-life and human figure drawing. We do not have step by step approach to teaching these above. For pottery, we were told to go and make a pot and even other pieces, but we weren't exposed to the theory part of it, not even the practical that we start like this and end like this. Yet we have to teach it at the secondary level (Focus group interview-5)

For me what I see as content gap is in ICT, because the computers are very expensive, and it is very hard to get notes for computer studies. For the art disciplines we missed at college are easy to teach yourself once you get a book or a pamphlet (interview, Paul)

IVATs' responses about the content gap they observe in secondary schools echoed similar disciplines like those they missed or inadequately handled at college during their pre-service teacher preparation. Apart from having limited knowledge of these disciplines, there are also very few secondary schools that can afford to facilitate the teaching of these disciplines. For they require specialized art materials, tools, equipment and adequate space for both studio and storage. Therefore, there is a need to equip learners with adequate knowledge and skills while still at teacher colleges that will enable them to be creative and adapt to different environments, they might find themselves in.

IVATs supported the idea of including local content into the improved VAC. They said that:

It is good and very vital to include and teach local content because as we teach using local content you teach a student what he knows. You refer to something they know; at times they have it at their home (Focus group interview-5).

IVATs identified crafts done by the artisans as important and good to include in the improved VAC. They mentioned that;

If you look at the syllabus it is rich because it even tells us to use the local artisans as resource persons in our community. It is only that we do not contact them we think they are not useful. The students themselves under look them because of their academic status (Focus group interview-2).

IVATs further explained that local content would have been good, and they like to teach it to their students, but it is poorly documented and very scarce. Yet the foreign content they observed that it is everywhere and even the current VAC emphasizes foreign material mainly. However, once the local content is made available to them, they were ready to teach it to their students. They also mentioned that local content motivates the learners, and it gives meaning to the art subject. However, a few of the IVATs expressed their fears regarding the quality of the local content as well as people's responses towards it since many Christian churches demonized the local artworks. Regardless of the IVATs' fears about local content, the rest of the responses support the reviewing of the VAC to allow restructuring which will lead to the inclusions of local content. 
Julius SSEGANTEBUKA, Patrick SSERUNJOGI, Ritah EDOPU, Timothy TEBENKANA, John Bosco KANUGE. In-service teachers' perceptions of the effectiveness of their pre-service art education program in Uganda

PROBLEMS

OF EDUCATION

IN THE $21^{\text {st }}$ CENTURY Vol. 79 , No. 1, 2021

IVATs responded positively to the question about the content knowledge a well-trained art teacher should possess. Majority of the IVATs noted that an art teacher should have knowledge of practical, theory, delivery of content and assessment methods. IVATs further explained that; "the ability to demonstrate to learners, effective communication, being enterprising and exemplary are important elements of the needed content knowledge for a well-trained art teacher" (Focus group interview-3). One IVAT was quoted saying; "A well-trained teacher should know the methods of teaching. A good teacher you must know how to deliver the content, how to evaluate and even do the work together with the learners". Another IVAT stated that; "The teacher must be in the know of modern pedagogy like demonstration, discussion, and share pair because the learners have a lot of information, we can also learn from them". IVATs' responses about the content knowledge a well-trained art teacher must possess support the quest to review the current VAC so that the content is sequenced, detailed and updated to meet the $21^{\text {st-century }}$ demands.

\section{Teaching Methods Tutors Frequently Used}

It is worth noting that almost of all the IVATs identified free expression, group methods, lecture methods, critique and direct observation as the teaching methods frequently used by their tutors in VA. Additionally, about a third of IVATs prioritized discussion, research, demonstration, project methods, and peer teaching method as the teaching methods frequently used by their tutors in $V A$. However, some IVATs noted that;

Critique and research as a teaching method were not well handled and the project methods came at the end of the second year when we were about to end our two-year teacher preparation program. The lecturer come talks a lot about the renaissance, Stone Age, Caveman, Tombs etc. we have never been given a chance to research on our own to learn. Research as a method wasn't well done (Focus group interview-4).

IVATs noted that their tutors frequently used active teaching methods during teacher preparation. However, IVATs requested for a deeper understanding of some of these active teaching methods. In a follow-up question, IVATs reported using active teaching methods in their teaching in secondary schools where they are employed. For example, these IVATs prioritized the use of demonstration, guided discovery, direct observation, and discussion. A few of the IVATs mentioned limited use of group work and project methods in VAC. This supports the argument that teachers should be trained well because what they are exposed to inform their practices/performance when deployed to teach.

\section{Assessment Strategies Tutors Commonly Used}

Majority of the IVATs reported summative assessment as the most frequently used assessment strategy in $V A$. Limited use of formative assessment method was reported by IVATs. They mentioned that;

It was summative assessment at the end of the semester. You leave your work to the tutor and go. What follows is a mark displayed on the notice board you have a $70 \%$ but you do not know how it came about (Focus group interview-1).

Several participants were quoted saying;

We did not participate in the assessment. What I remember these people used to give us were course work but we still stayed with it up to the end of the year so we did not participate in marking (Focus group interview-2). 
Julius SSEGANTEBUKA, Patrick SSERUNJOGI, Ritah EDOPU, Timothy TEBENKANA, John Bosco KANUGE. In-service teachers' perceptions of the effectiveness of their pre-service art education program in Uganda

One of the IVATs tried to recall what their tutors used to do as far as assessment was concerned. He said;

I don't remember being assessed when am there, because the only task that I had was to display the work then they lock the room you wait for the marks at the end may be on the transcript.

This means that IVATs lack assessment skills simply because they never participated in assessing their artworks while at NTCs. However, some IVATs observed that they used to participate in the assessment by practicing peer assessment. A few IVATs noted that;

For us we used to have a weekly assessment. We were allowed to participate by talking about our artworks. In our college where I trained from, our tutors enjoyed using peer assessment. You do the artwork; you exchange as the tutor has told you and then start marking. The tutor collects what you have given your friend and then he compiles the mark (Focus group interview-5)

Generally, IVATs' responses indicated that the benefit was minimal as far as assessment was concerned. Most of them did not participate in the assessing of their artworks. The assessment was mainly done by their tutors only in the absence of the IVATs. When IVATs were asked which assessment strategies they use in their teaching, they listed critiquing, peer assessment, and grid marking. Some IVATs mentioned that they group students' works and then later they award marks. Although IVATs were able to mention some of the assessment strategies they use during teaching, they faced challenges when it came to explaining in detail a particular assessment strategy and how it is applied.

\section{Resources in Art Teacher Preparation}

The only resources in art IVATs concentrated on were art materials, tools, equipment and art textbooks. IVATs mentioned that the colleges did not have art textbooks. They depended on tutors' notes and at times they used locally produced pamphlets. One IVAT was quoted saying;

The fact I did not know that there is any art book that exists. During high school, I had never seen any art book. When we came to college it was the same, I did not see any tutor with any art textbook

The IVAT's response showed that there was little interaction with the teaching resources from which he was supposed to learn information search and presentation. However, this is a challenge many face even with improved access to digital libraries through computers and smartphones they have.

For the issue of art materials, tools and equipment, IVATs reported that they were not provided with art materials, tools and equipment during their teacher preparation. The college administrations were only able to provide art materials strictly for instructional purposes to tutors. They had limited access to the desired art materials and tools. This means that they left the college with limited knowledge in using most of the art materials, tools, and equipment.

\section{Discussion}

The research aimed at establishing how IVATs in Uganda viewed their pre-service art teacher education program by describing and examining its effectiveness. The findings of the study revealed that the IVATs found it easy to teach pottery, graphic design, still-life, nature studies and studio technology. They explained that these art disciplines were easy to teach because of the availability of the art materials they use during teaching. This was in 
Julius SSEGANTEBUKA, Patrick SSERUNJOGI, Ritah EDOPU, Timothy TEBENKANA, John Bosco KANUGE. In-service teachers' perceptions of the effectiveness of their pre-service art education program in Uganda

PROBLEMS

OF EDUCATION IN THE $21^{\text {st }}$ CENTURY Vol. 79 , No. 1,2021

128

agreement with Masette (personal communication, February 13, 2020) who states that teachers concentrate on teaching disciplines whose materials and other resources are available because they simply tell learners to copy compositions in books and they paint or draw. However, during the interviews, it was discovered that these disciplines were not only easy to teach because the art materials they use were available, but there were also the disciplines they adequately handled during their teacher preparation while at teacher colleges. This confirms what DarlingHammond (2009) stated that students will always learn what their teachers know.

Results of the study revealed that drawing as a discipline was composed of three wide areas they were supposed to study; they included still-life, nature studies and human figure drawing. However, IVATs clarified that they did not study human figure during their pre-service arts education, just because they lacked studio space and models who would pose for them. It was also found out that their tutors had limited knowledge of figure drawing. This manifested itself in the way tutors failed to improvise by instructing fellow learners to pose for each other. The findings implied that IVATs did not acquire the necessary knowledge and skills needed in teaching human figure drawing. This explains as to why IVATs find it difficult to teach human figure drawing to their secondary school art students. The findings confirm Kagoda and Ezati (2013) argument that teachers will always teach how they were taught and only teach what they know.

The study findings further revealed several art disciplines which were poorly taught to the IVATs while at college. These art disciplines included but not limited to painting, weaving, history of art and art appreciation, and sculpture and studio technology. Like human figure drawing, IVATs find it difficult teaching these art disciplines to their arts students in secondary schools for lack of the desired knowledge. They instead omit them where possible or give the little they know, leading to surface learning in secondary schools (Omar, 2014; Ssegantebuka, 2019). The probable causes for inadequate handling of these art disciplines were that they demanded much more in terms of art materials, tools and equipment which the colleges did not provide. The findings also indicated that study areas like weaving, figure drawing and printmaking were not stand-alone; they were combined with other art disciplines. For instance, the textile decoration was combined with weaving and graphic design was combined with printmaking, thus promoting omission during teaching as observed by Nbina (2010).

IVATs mentioned that they used YouTube videos, attended workshops, consulted colleagues, and copied from pamphlets and some textbooks, to teach themselves the art disciplines they missed or inadequately handled during their pre-service teacher education. Findings from the interviews point to the need to equip our learners with the knowledge and skills to help them interact with different teaching resources including information communication and technologies (Cherner \& Curry, 2017; Mishra \& Koehler, 2006).

IVATs reported history of art and art appreciation as the discipline policymakers should remove from the VAC. The findings of the study indicated that the resources IVATs used for the history of art and art appreciation while at college were very hard to understand. Secondly, the teaching of the history of art was inadequately handled by their tutors. Therefore, IVATs never developed the confidence to teach the history of art and art appreciation to their secondary school art students. When teachers do not develop the confidence to teach a given subject matter is a manifestation of limited content knowledge (Ketitia, 2015).

IVATs revealed that local art and craft content was included in the VAC, but they were not exposed to it during their teacher preparation. This means that the IVATs did not develop the appreciation of the local art and crafts while still at college during their early years of formation as art teachers. The findings of the study further revealed that the local art and craft content was poorly documented and very scarce compared to the foreign content which was emphasized in the current VAC. 
Julius SSEGANTEBUKA, Patrick SSERUNJOGI, Ritah EDOPU, Timothy TEBENKANA, John Bosco KANUGE. In-service teachers' perceptions of the effectiveness of their pre-service art education program in Uganda

\author{
PROBLEMS \\ OF EDUCATION \\ IN THE $21^{\text {st }}$ CENTURY
}

The results of the study showed that IVATs were aware of the content knowledge a welltrained art teacher should possess. This awareness helped them to reflect on what they know and doing with their secondary school art students. They were able to identify the content gaps in their teaching. It was found out that an art teacher should have knowledge of practical, theory, delivery of content, demonstration, discussion, share pair, and assessment methods. IVATs further explained that ability to demonstrate to learners, effective communication, being enterprising and exemplary were important elements of the needed content knowledge for a well-trained art teacher. IVATs' responses about the content knowledge a well-trained art teacher must possess supported the quest to review the current VAC so that the content is sequenced, detailed

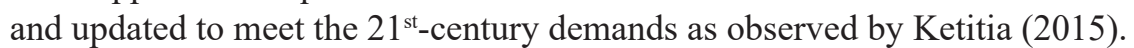

Free expression, group methods, lecture methods, discussion, project methods, peer teaching method, critique and direct observation were identified by IVATs as the teaching methods frequently used by their tutors in VA. This explains as to why IVATs mentioned that they also use similar active teaching methods in secondary schools. This supports the argument that teachers should be trained well because what they are exposed to informs their practices/performance when deployed to teach (Eret-Orhan et al., 2018; Ssegantebuka, 2018).

The results of the study showed that tutors frequently used active teaching methods during pre-service teacher education. However, to-date, IVATs still request for a deeper understanding of some of these active teaching methods. This means that some of these teaching methods were not adequately practiced for IVATs to acquire the necessary knowledge. It was also discovered that there were some active teaching methods IVATs talked about but not practiced in their secondary schools where they are currently employed. They felt that some of the teaching methods are time-consuming, need bigger spaces and other teaching methods you must have enough art materials if you are going to use them.

The findings of the study reported limited use of formative assessment method at college. What they commonly used was summative assessment. This means that some of the IVATs did not get the opportunity to practice assessment while at college (Ssegantebuka, 2016). Although some IVATs participated in the assessment by practicing peer assessment while still at college, most of them did not participate in the assessing of their artworks. This means that IVATs did not acquire skills in assessing VA, a situation that has affected their performance in secondary schools where they are currently employed to teach $V A$ to their students.

IVATs revealed that they used critiquing, peer assessment, grid marking, group students' works and then later they award marks. However, they faced challenges when it came to explaining in detail a particular assessment strategy how it is applied. IVATs' responses indicated that the benefit was minimal as far as assessment was concerned while still at college. The tutors' failure to practically demonstrate desired assessment strategies made it difficult for their IVATs to acquire $V A$ assessment skills which they were supposed to learn while still at college (Eret-Orhan et al, 2018; Ssegantebuka, 2016).

The results of the study revealed that art textbooks were scarce. IVATs depended on tutors' notes and locally produced pamphlets which were not peer-reviewed. The findings showed that there was little interaction with the art textbooks from which they were supposed to learn information search and presentation (Mishra \& Koehler, 2006). This is a challenge they still face even with improved access to computers and smartphones they have.

Besides, IVATs were not provided with art materials, tools and equipment during their pre-service teacher preparation. It was observed that the only art materials the college administrations provided were for instructional purposes only (Tebenkana, 2011). This means that IVATs left colleges with limited knowledge in using most of the art materials, tools and equipment an issue they reported affecting their performance in secondary schools to-date. The scarcity of art materials, tools and equipment affects skills acquisition in VA as observed by Ssegantebuka (2016). 
Julius SSEGANTEBUKA, Patrick SSERUNJOGI, Ritah EDOPU, Timothy TEBENKANA, John Bosco KANUGE. In-service teachers' perceptions of the effectiveness of their pre-service art education program in Uganda

\author{
PROBLEMS \\ OF EDUCATION \\ IN THE $21^{\text {st }}$ CENTURY \\ Vol. 79 , No. 1, 2021 \\ 130 Conclusions
}

Effective pre-service art teacher education program is desired for it equips PVATs with the opportunity to acquire knowledge and skills needed in VA teaching while still at college. Therefore, it is important to research the different aspects that make the pre-service art teacher education program effective. In this case, there is a need to restructure the VAC and separate the combined art disciplines so that each art discipline is studied independently. Once this is done, it will reduce on the omission of some art disciplines and surface learning. As a result, it will support adequate content coverage in the NTCs in Uganda.

The current selective teaching of the content is encouraged by the nature of the VAC that does not stipulate the knowledge base to be acquired before graduation. IVATs also raised the need to restructure the current VAC to integrate ICT in art teaching. It was observed that ICT knowledge and skills help the learners interact with different teaching resources including information search and presentation in VA teaching hence further learning.

There is also a need to ensure practical application of the active teaching methods before learners leave teacher colleges. Expose learners to formative assessment as well as availing them with the opportunity to practice peer assessment of their artworks. NTC administrations should take up the responsibility to provide teaching resources to the learners during preparation to ensure the availability and uniformity of the teaching resources. The availability of adequate teaching resources exposes learners to a variety of techniques and necessary information expected of a qualified teacher. Once the above recommendations are put in place, an effective pre-service art teacher education program is certain.

\title{
Acknowledgement
}

The authors are deeply grateful and appreciate the financial support from the Government of Uganda through Makerere University Research and Innovations Fund.

\section{References}

Aguti, J. N. (2005). A study of in-service distance education for secondary school teachers in Uganda: Developing a framework for quality teacher education programs (Doctoral dissertation, University of Pretoria).

Barnes, H., \& Verwey, H. (2008). Teacher education review. University of Pretoria.

Berry, A., \& Van-Driel, J. H. (2013). Teaching about teaching science: Aims, strategies, and backgrounds of science teacher educators. Journal of Teacher Education, 64(2), 117-128. https://doi.org/10.1177\%2F0022487112466266

Bryman, A. (2012). Social research methods (4th ed.). Oxford University Press.

Cheng, Y. C. (2005). New paradigm for re-engineering education: Globalization, localization and individualization (Vol. 6). Springer Science \& Business Media.

Cherner, T., \& Curry, K. (2017). Enhancement or transformation? A case study of pre-service teachers' use of instructional technology. Contemporary Issues in Technology and Teacher Education, $17(2), 268-290$.

Creswell, J. W. (2012). Collecting qualitative data. Educational Research: Planning, Conducting and Evaluating Qualitative and Quantitative Research. $4^{\text {th }} \mathrm{ed}$., 204-35. Pearson.

Darling-Hammond, L. (2009). Recognizing and enhancing teacher effectiveness. The International Journal of Educational and Psychological Assessment, 3, 1-24. https://psycnet.apa.org/record/2010-11469-001

Diploma in Secondary Education. (2002). Art and craft module AC/3. Kyambogo University.

Eret-Orhan, E., Ok, A., \& Capa-Aydin, Y. (2018). We train, but what do they think? Pre-service teachers' perceptions of the adequacy of their teacher education in Turkey. Asia-Pacific Journal of Teacher Education, 46(2), 183-198. https://doi.org/10.1080/1359866X.2017.1355050 
Julius SSEGANTEBUKA, Patrick SSERUNJOGI, Ritah EDOPU, Timothy TEBENKANA, John Bosco KANUGE. In-service teachers' perceptions of the effectiveness of their pre-service art education program in Uganda

Feiman-Nemser, S. (2001). Helping novices learn to teach: Lessons from an exemplary support teacher. Vol. 79 , No. 1, 2021 Journal of Teacher Education. 52(1), 17-30. https://doi.org/10.1177/0022487101052001003

Fraenkel, J.R. \& Wallen, N.E. (2006). How to Design and Evaluate Research in Education. (4th ed.). McGraw-Hill.

Gray, D. E. (2009). Doing research in the real world (2nd Ed.). Sage Publication.

Gurney, P. (2007). Five factors for effective teaching. New Zealand Journal of Teachers' Work, 4(2), 8998.

Jonassen, D. H., Howland, J., Moore, J., \& Marra, R. M. (2003). Learning to solve problems with technology: A constructivist perspective (2nd Ed.). Pearson Education.

Kagoda, A. M., \& Ezati, B. A. (2013). Contribution of primary teacher education curriculum to quality primary education in Uganda. Problems of Education in the 21st Century, 52, 35-47. http://www.scientiasocialis.lt/pec/node/506

Kagoda, A. M. (1997). Geography Education in Uganda. [Unpublished doctoral thesis]. University of Alberta, Canada.

Katitia, D. M. O. (2015). Teacher education preparation program for the 21 st Century. Which way forward for Kenya. Journal of Education and Practice, 6(24), 57-63.

Ladwig, J. G. (1991). Is collaborative research exploitative? Educational Theory, 41(2), 111-120. https://doi.org/10.1111/j.1741-5446.1991.00111.x

McPhee, A. D., Forde, C., \& Skelton, F. (2003). Teacher education in the UK in an era of performance management. Asia Pacific Journal of Teacher Education and Development, 6(2), 37-56. https://eprints.gla.ac.uk/archive/00000117

Mezirow, J. (1991a). Transformative dimensions of adult learning. Jossey-Bass.

Miles, M. B., \& Huberman, A. M. (1994). Qualitative data analysis: An expanded sourcebook. Sage Publication.

Mishra, P., \& Koehler, M. J. (2006). Technological pedagogical content knowledge: A framework for teacher knowledge. Teachers College Record, 108(6), 1017-1054. https://www.learntechlib. org/p/99246/

Morgan, D. L. (1997). The focus group guidebook. Sage Publications. https://dx.doi.org/10.4135/9781483328164

Mpowe, L. T. (2002). A thematic based professional studies art education curriculum for training junior secondary school art teachers in Botswana (Doctoral dissertation).

National Research Council. (2001). Testing teacher candidates: The role of licensure tests in improving teacher quality. National Academies Press.

Nbina, J. B. (2012). Teachers' competence and students' academic performance in senior secondary schools' chemistry: Is there any relationship? Global Journal of Educational Research, 11 (1), 15-18.

Odiya, J. N. (2009). Scholarly writing: Research proposals and reports in APA or MLA publication style. Makerere University Printery.

Omar, C. M. Z. C. (2014). The need for in-service training for teachers and its effectiveness in school. International Journal for Innovation Education and Research, 2(11), 1-9.

Patton, M. Q. (2002). Qualitative research and evaluation methods ( $3^{\text {rd }}$ ed.). Sage Publications.

Rubin, H. J., \& Rubin, I. S. (2005). Qualitative interviewing: The art of hearing data ( $2^{\text {nd }}$ ed.). Sage Publications.

Scannell, D. P. (2002). Models of teacher education. Report to the American council of education presidents' task force on teacher education.

Hussain, S. (2004). Effectiveness of teacher training in developing professional attitude of prospective secondary school teachers (Doctoral dissertation, PMAS-Arid Agriculture University, Rawalpindi).

Ssegantebuka, J. (2016). Tutors' knowledge-base and the preparation of pre-service visual arts teachers in Uganda [Unpublished doctoral thesis]. Makerere University.

Ssegantebuka, J. (2018). Pre-service visual arts teachers' perceptions of their experiences of school practice: A case of national teacher college in Uganda. Academic Journal of Interdisciplinary Studies, 7(1), 45-45. https//doi.org/10.2478/ajis-2018-0004 
Julius SSEGANTEBUKA, Patrick SSERUNJOGI, Ritah EDOPU, Timothy TEBENKANA, John Bosco KANUGE. In-service teachers' perceptions of the effectiveness of their pre-service art education program in Uganda

PROBLEMS

OF EDUCATION

IN THE $21^{\text {st }}$ CENTURY Vol. 79 , No. 1,2021

132

Ssegantebuka, J. (2019). Pre-service visual arts teachers' perceptions of the effectiveness of their methods course in national teacher colleges in Uganda. European Journal of Education Studies, 6(9), 102122. https://dx.doi.org/10.5281/zenodo.3583476

Stake, R. E. (1995). The art of case study research. Sage Publications.

Taylor, E. W. (1998). The theory and practice of transformative learning: A critical review. information series No. 374.

Tebenkana, T. (2010). Efficacy of the distance education mode in the training of art and design teachers at Makerere University [Unpublished doctoral thesis]. Makerere University.

Vegas, E., Loeb, S., Romaguera, P., Paglayan, A., Goldstein, N., Ganimian, A., \& Jaimovich, A. (2012). What matters most in teacher policies? A framework for building a more effective teaching profession. SABER Report.

Received: September 01, 2020

Accepted: January 28, 2021

Cite as: Ssegantebuka, J., Sserunjogi, P., Edopu, R., Tebenkana, T., \& Kanuge, J. B. (2021). In-service teachers' perceptions of the effectiveness of their pre-service art education program in Uganda. Problems of Education in the $21^{\text {st }}$ Century, 79(1), 118132. https://doi.org/10.33225/pec/21.79.118

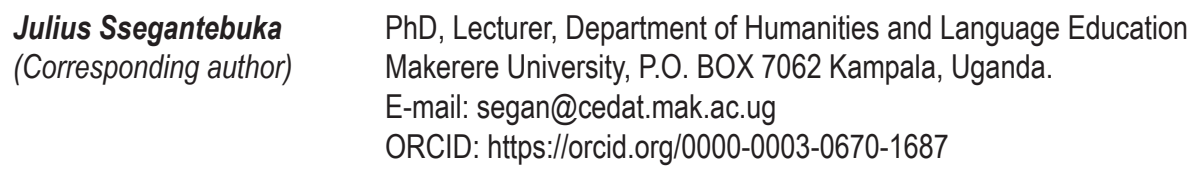

Julius Ssegantebuka

(Corresponding author)

$\mathrm{PhD}$, Lecturer, Department of Humanities and Language Education

Makerere University, P.O. BOX 7062 Kampala, Uganda.

E-mail: segan@cedat.mak.ac.ug

ORCID: https://orcid.org/0000-0003-0670-1687

Patrick Sserunjogi

Lecturer, Department of Art and Industrial Design, Makerere University, 7062

Kampala, Uganda.

E-mail: ptsseru@gmail.com

Ritah Edopu

Lecturer, Department of Fine Arts, Makerere University, 7062 Kampala, Uganda.

E-mail: rnedopu@gmail.com

Timothy Tebenkana

Senior Lecturer, Department of Humanities and Language Education,

Makerere University, 7062 Kampala, Uganda.

E-mail: ttebenkana@cees.mak.ac.ug

John Bosco Kanuge
Lecturer, Department of Art and Industrial Design, Makerere University, 7062

Kampala, Uganda.

E-mail: jbkanuge@googlemail.com, jbkanuge@cedat.mak.ac.ug 